\title{
EPIDEMIOLOGY AND SURGICAL TREATMENT OF GASTRIC CANCER IN LATVIA
}

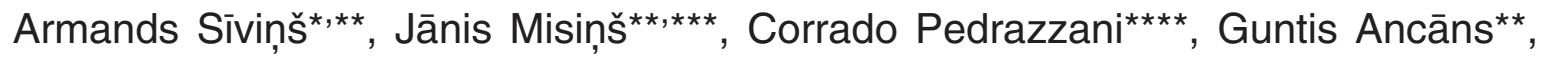 \\ Aivars Stengrēvics*, Viesturs Krūminš ${ }^{*}$, Viesturs Boka*, Mārcis Leja ${ }^{*, * *}$ \\ * Rīga Eastern Clinical University Hospital, Latvia Oncology Centre, Hipokrāta iela 4, Rīga, LV-1006, LATVIA; \\ e-mail: armands1@ hotmail.com \\ ${ }^{* *}$ Faculty of Medicine, University of Latvia, Šarlotes iela 1a, Rīga, LV-1001, LATVIA \\ ${ }^{* * *}$ Health Statistics and Medical Technologies State Agency, Duntes iela 12/22, Rīga, 1005, LATVIA \\ ${ }^{* * * *}$ Department of Human Pathology and Oncology, University of Siena, Via Banchi di Sotto 55, Siena, 53100, ITALY
}

Communicated by Andrejs Ërglis

\begin{abstract}
The aim of the study was to evaluate short- and long-term results of surgical treatment of gastric cancer performed in Latvia Oncology Centre. Retrospectively data was collected from 461 patients who underwent gastrectomy with curative intent in the Latvia Oncology Centre from January 2001 to December 2005. The data was subjected to statistical analysis. On average, 92.2 (range 81-102) R0-R1 gastrectomies were performed each year. Post-operative complications occurred in 75 patients (16.3\%); in-hospital mortality was 3.3\%. The overall 5-year survival was $50.8 \%$. In 444 cases (96.3\%) there was histopathologic confirmation of R0-resection with a 5-year survival of 52.5\% ( $\mathrm{P}<0.001)$. Considering pT category, 5-year survival (median) was $88.6 \%$ (not reached) for pT1 patients, 65\% (not reached) for pT2, 42.3\% (35.7 months) for pT3 and 27\% (14.2 months) for pT4 ( $\mathrm{P}<0.001)$. Considering the $\mathrm{pN}$ category, 5-year survival (median) was 67\% (not reached) for pNO patients, 30\% (22.1 months) for pN1 and 29\% (14.2 months) for pN2-3 $(\mathrm{P}<0.001)$. Short- as well as long-term results are comparable with Western experiences, but not for $p N+$ patients where no difference between $p N 1$ and $p N 2$ cases was observed.
\end{abstract}

Key words: gastric cancer, epidemiology, surgical treatment.

\section{INTRODUCTION}

Gastric cancer remains one of the most common tumours worldwide (Devesa et al., 1998). Although the mortality is decreasing in Western Europe and North America, it still remains rather high in Eastern European countries (Ferlay et al., 2007). Gastric cancer in Latvia reaches the $4^{\text {th }}$ place among tumours in incidence $\left(3^{\text {rd }}\right.$ place in males and $7^{\text {th }}$ in females) in Latvia with an ASR incidence of 24.6 per 100,000 population (Latvian Cancer Registry, data on file 2008). The aim of this study was to evaluate the results of surgical treatment of gastric cancer performed with radical intent in Latvia Oncology Centre in order to determine postoperative complications, mortality and long-term survival.

\section{PATIENTS AND METHODS}

Inclusion criteria and population under study. Retrospective analysis was performed on patients who had undergone macroscopic potentially curative (R0-1) gastrectomy for primary gastric adenocarcinoma in the Latvia Oncology Centre from January 2001 to December 2005.
Surgery. The main purpose of surgery was R0 resection of the tumour. The indication for performing either total or subtotal gastrectomy was based on tumour location, surgical tumour-free margins and macroscopic appearance of the tumour. Subtotal gastrectomy was preferred for non-infiltrative tumours located in the lower and middle third of the stomach provided that the proximal resection margin was at least $6-8 \mathrm{~cm}$ from the tumour edge, otherwise total gastrectomy was carried out. Limited lymphadenectomy was performed in each case with division of left gastric vessels at the origin. Antecolic Billroth II reconstruction was used after subtotal gastrectomy, while jejunal Roux-en-Y or Braun reconstruction was performed after total gastrectomy according to surgeon preference.

Histopathological staging. Histologic analysis was performed to confirm adenocarcinoma diagnosis, define tumour differentiation and confirm the complete removal of the tumour. The most recent TNM classification of the American Joint Committee on Cancer (AJCC) and International Union against Cancer (UICC) was used for pathologic classification (pTNM) and definition of residual tumour ( $\mathrm{R}$ classification). Number of analysed nodes was 
recorded for 231 patients; in this regard, it is important to specify that in our routine not all excised lymph nodes were analysed. However, a limited number of nodes are randomly sampled by a pathologist (mean 5.6; range 0-21).

Data collection and follow-up. Data were retrospectively collected by chart review by physicians and physician assistants. Among others, data regarding personal and medical information, surgery, post-operative course, histopathologic examination were collected and stored in a database. Survival status and eventual date and cause of death were collected through the Latvia Cancer Registry. The median follow-up period for surviving patients was 57.5 (range 29-89) months.

Statistical analysis. The Chi-square test was used for categorical data and the ANOVA test for continuous variables. Survival curves were estimated using the KaplaneMeier method and compared by the log-rank test. Death from causes other than gastric cancer was considered censored observations at the time of death. Each demise occurring in-hospital or within 30 days was considered as postoperative mortality and used in survival analysis. Statistical analyses were performed using Statistical Product and Service Solutions, SPSS 14.0 for Windows, XP, SPSS Inc., Chicago IL.

\section{RESULTS}

Population under study. During the study period, 461 patients underwent resection with curative intent (R0-R1). On average, 92.2 (range 81-102) R0-R1 gastrectomies were performed each year. Median age of the cohort was 65 years (range 23-89) with a male to female ratio of $1.2: 1$.

Short-term results. Postoperative general and surgical complications occurred in 75 patients $(16.3 \%)$ and, of these 15 consequently died (post-operative mortality, 3.3\%). Morbidity complicated post-operative course in 36 total gastrectomies, 34 subtotal gastrectomies and four proximal gastrectomies $(P<0.05)$. Mortality was slightly higher for total gastrectomy $(4.8 \%)$ compared to subtotal $(2 \%)$ and proximal resections $(4 \%) \quad(P<0.05)$.

Survival according to completeness of tumour resection ( $R$ classification). The overall median survival time for the 461 patients was beyond the observation period with 2 - and 5 -year survival rates of $63.9 \%$ and $50.8 \%$. In 444 cases there was histopathologic confirmation of curative resection (R0), while a microscopic residual tumour (R1) was demonstrated in 17 cases. When R0 resection was obtained the 5year survival was $52.5 \%$ while the survival rate fell to $5.9 \%$ at 43 months (median, 9.4 months) when a residual tumour was observed $(P<0.001)$.

Survival according to tumour location and depth of tumour invasion (pT). Survival curves for R0-resected patients according to tumour location are depicted in Figure 1. Figure 2 shows Kaplan-Meier estimates of survival probability according to the depth of tumour invasion (pT).

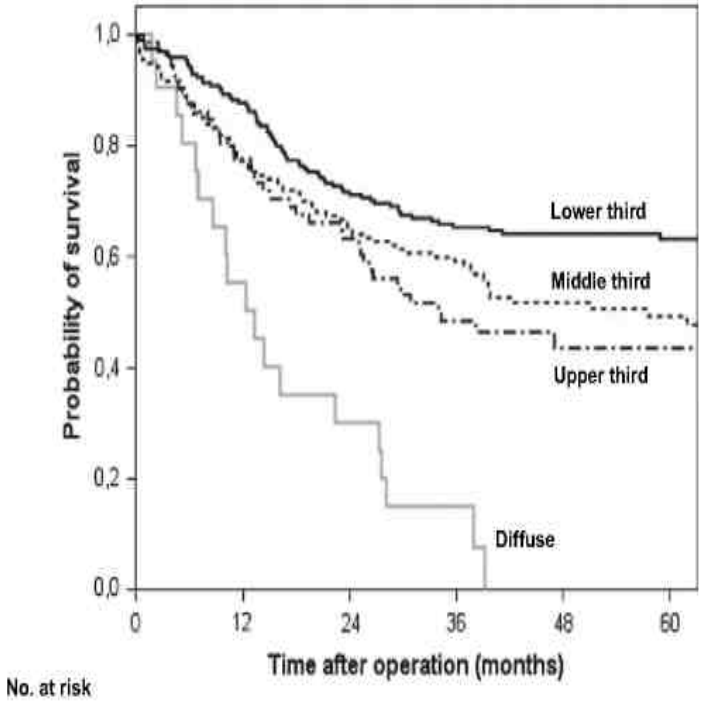

$\begin{array}{lcccccc}\text { Upper third } & 72 & 54 & 44 & 26 & 15 & 8 \\ \text { Middle third } & 155 & 117 & 97 & 80 & 52 & 34 \\ \text { Lower third } & 196 & 171 & 137 & 116 & 94 & 68 \\ \text { Diffuse } & 21 & 11 & 6 & 2 & & \end{array}$

Fig. 1. Kaplane-Meier estimates of survival probability according to tumour location in 444 patients who underwent R0 gastrectomy. Median (95\% CI) survival time was beyond the observation period for lower and middle third tumours; 34 (14.8-53.1) months for upper third tumours and 13.3 (7.2-19.3) months for diffuse tumours; $(P<0.001)$.

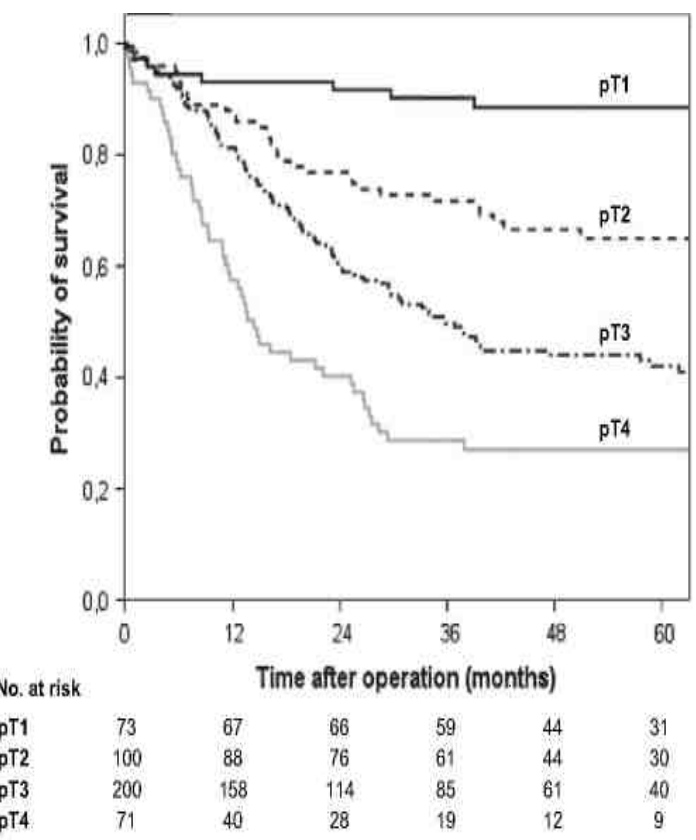

Fig. 2. Kaplane-Meier estimates of survival probability according to depth of tumour invasion (pT) in 444 patients who underwent R0 gastrectomy. Median $(95 \% \mathrm{CI})$ survival time was beyond the observation period for $\mathrm{pT} 1$ and pT2 tumours; 35.8 (28.9-42.7) months for pT3 tumours and 14.3 (10.7-18) months for pT4 tumours; $(P<0.001)$.

Survival according to lymph node involvement (pN). Considering nodal involvement, the 5 -year survival rate was $67 \%$ for pN0 patients, $30 \%$ for $\mathrm{pN} 1$ and $29 \%$ for $\mathrm{pN} 2-3$ $(P<0.05)$. Restricting the analysis to $\mathrm{pN}+$ cases, no difference was demonstrated between $\mathrm{pN} 1$ and $\mathrm{pN} 2-3$ subsets $(P<0.05)$ (Fig. 3). 


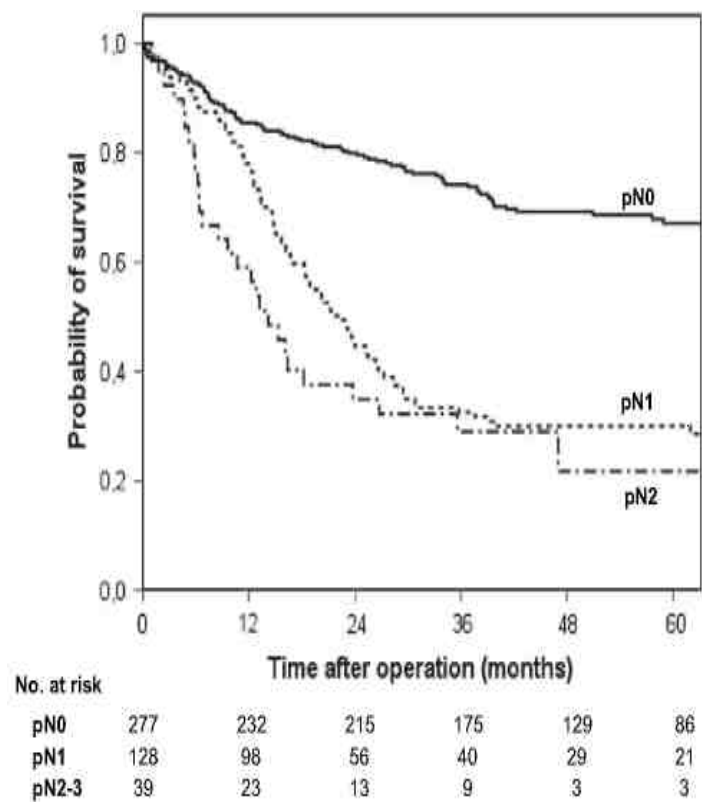

Fig. 3. Kaplane-Meier estimates of survival probability according to nodal involvement $(\mathrm{pN})$ in 444 patients who underwent R0 gastrectomy. Median $(95 \% \mathrm{CI})$ survival time was beyond the observation period for $\mathrm{pN} 0$ tumours; 22.1 (18.1-26.1) months for pN1 tumours and 14.2 (9.7-18.7) months for pN2-3 tumours; $(P<0.001)$.

Survival according to pTNM stage. Considering pTNM staging, the 5-year survival rate was $89.7 \%$ for 71 Stage IA patients, $72.6 \%$ for 81 Stage Ib, $52.9 \%$ for 113 Stage II, $34.8 \%$ for 105 Stage IIIA, $27.4 \%$ for 26 Stage IIIb and $18.7 \%$ for 48 Stage IV $(P<0.001)$.

\section{DISCUSSION}

Major findings. Major findings of this study are: 1) morbidity and mortality are similar to those reported by high volume centres in Western Europe and United States, and 2) survival rates are almost equal, particularly for patients with nodal involvement, for which no significant difference was found between $\mathrm{pN} 1$ and $\mathrm{pN} 2-3$ cases.

Gastric cancer in Latvia. The Latvian Cancer Registry data was used to preview gastric cancer incidence in Latvia for the time period 1980-2007 (Fig. 4) and mortality for time period 1991-2007 (Fig. 5). The proportions of stages of new gastric cancer cases in Latvia for 2001-2007 are shown in Table 1. Five-year observed survival for patients with gastric cancer in Latvia in percent was examined for the time period 1988-2002 (Fig. 6). Although the incidence of gastric cancer and mortality caused by this malignancy are decreasing in Latvia, the rates are still considerably higher than on average in the EU. While the number of gastroscopies is increasing the proportion of early diagnosed new gastric cancer cases is still low. Radical resection still remains the mainstay of therapy for gastric cancer and, unfortunately, only a minority of Latvia patients match oncologic criteria to undergo surgery with curative intent.

Results of surgery. In spite of the very advanced stage in the great majority of Latvia patients, clinico-pathological

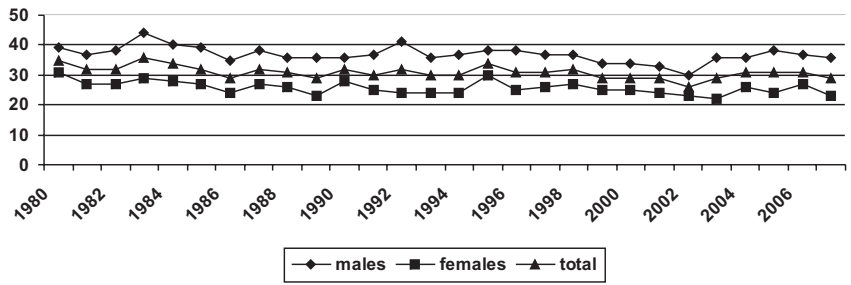

Fig. 4. Incidence of gastric cancer in Latvia, crude rate per 100,000 Latvia population.

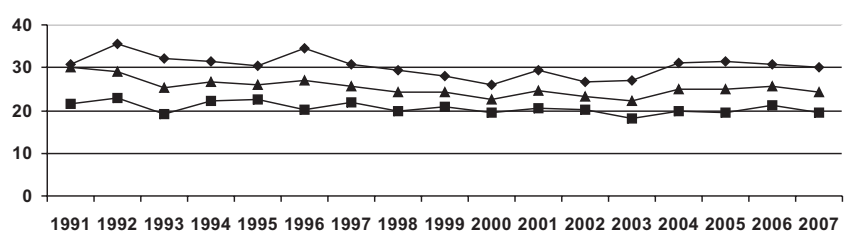

$\rightarrow-$ males $\rightarrow-$ females $\rightarrow-$ total

Fig. 5. Gastric cancer caused mortality in Latvia, crude rate per 100,000 Latvia population.

Table 1

STAGE OF NEW GASTRIC CANCER CASES IN LATVIA, \%

\begin{tabular}{l|c|c|c|c|c|c|c}
\hline & 2001 & 2002 & 2003 & 2004 & 2005 & 2006 & 2007 \\
\hline I stage & 6.6 & 7.6 & 7.8 & 8.4 & 9.2 & 7.9 & 8.4 \\
II stage & 13 & 14.1 & 16 & 12.6 & 15.2 & 14.2 & 11.2 \\
III stage & 26.1 & 22.4 & 22.8 & 24.4 & 23.5 & 23.8 & 22.9 \\
IV stage & 49.8 & 50.4 & 46.9 & 45.8 & 44.3 & 44.5 & 45.9 \\
Unknown & 4.5 & 5.5 & 6.4 & 8.7 & 7.8 & 9.5 & 11.7
\end{tabular}

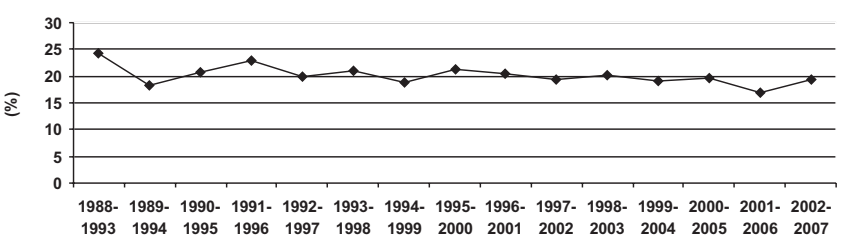

Fig. 6. Five-year observed survival for patients with gastric cancer in Latvia, in \% (year of diagnosis used as the reference year).

characteristics of gastric cancer cases resected with curative intent are comparable with those of Western Europe and North America (Songun et al., 1996). Particularly, the number of patients with positive resection margins is well above 5\%, similar to that reported in the literature (Songun et al., 1996; Fujimoto et al., 1997; Sano and Mudan, 1999). The small number of R1-patients and the overall 5-year survival rate, which approaches $50 \%$, provides evidence of the quality of surgical treatment in this setting. Above all, long-term results were positively influenced by the low morbidity and mortality observed in this series.

Assessment of adjacent organ invasion. Considering depth of tumour invasion, serosal invasion is typical for the majority of tumours $(62.5 \%)$. Regarding pT4 cases $(18 \%)$, there may have been inaccurate determination of intraoperative stage related to overestimation by the operating sur- 
geons (and pathologic stage) as well as from the retrospective nature of data collection. This seems to be confirmed by the unexpected 5-year survival rate of $27 \%$ observed in pT4 cases (Fig. 2) (Nanthakumaran et al., 2005; Kunisaki et al., 2006).

Assessment of nodal involvement. Regarding nodal involvement $(\mathrm{pN})$, a very high rate of node negative patients was observed (61\%) (Harrison et al., 1998; Roviello et al., 2002; Di Leo et al., 2007). Among pN+ patients, the great majority of patients showed 1-6 positive nodes, $22 \%$ had 7-15 metastatic nodes and only one more than 15 nodes. These results may be related to the very low number of analysed nodes, usually five or less (mean, 5.6; range, 0-21). In the present study only 24 patients had more than ten analysed nodes and four more than 15. This may have caused determination of imprecise nodal stage, as demonstrated from the lack of survival difference between $\mathrm{pN} 1$ and $\mathrm{pN} 2$ cases (Fig. 3). The low number of examined nodes seems to be due, over and above surgical technique, to a perceived lack of need by pathologists to retrieve more lymph nodes from resected specimens. This conclusion is supported by survival results that are comparable to other European and United States high volume centres (Edwards et al., 2004; Enzinger et al., 2007), although they are not as good as those reported after extended lymphadenectomy (Siewert et al., 1993; Maeta et al., 1999; Roviello et al., 2002; Sasako et al., 2008).

In conclusion, our data confirm that the strategy to concentrate gastric cancer surgery in high volume centres with relevant expertise has been a correct approach in our country and should be recommended as a standard. The results indicate the need to improve histopathological examination of stage and extent of lymphadenectomy.

\section{ACKNOWLEDGEMENTS}

The work was supported by the National Research Programme in Medicine 2006-2009, project No. 3, "Development of diagnostic methods for detection of cancer risk factors, early diagnostics of cancer and pre-cancer conditions, and optimisation of tumour treatment".

Received 11 July 2009

\section{REFERENCES}

Devesa, S.S., Blot, W.J., Fraumeni, Jr. J.F. (1998). Changing patterns in the incidence of esophageal and gastric carcinoma in the United States. Cancer, 83(10), 2049-2053.

Di Leo, A., Marrelli, D., Roviello, F. (2007). Lymph node involvement in gastric cancer for different tumor sites and T stage: Italian Research Group for Gastric Cancer (IRGGC) experience. J. Gastrointest. Surg., 11(9), 1146-1153.

Edwards, P., Blackshaw, G.R., Lewis, W.G., Barry, J.D., Allison, M.C., Jones, D.R. (2004). Prospective comparison of D1 vs modified D2 gastrectomy for carcinoma. Brit. J. Cancer, 90(10), 1888-1892.

Enzinger, P.C., Benedetti, J.K., Meyerhardt, J.A. (2007). Impact of hospital volume on recurrence and survival after surgery for gastric cancer. Ann. Surg., 245(3), 426-434.

Ferlay, J., Autier, P., Boniol, M., Heanue, M., Colombet, M., Boyle, P. (2007). Estimates of the cancer incidence and mortality in Europe in 2006. Ann. Oncol., 18(3), 581-592.

Fujimoto, S., Takahashi, M., Mutou, T., Kobayashi, K., Toyosawa, T., Ohkubo, H. (1997). Clinicopathologic characteristics of gastric cancer patients with cancer infiltration at surgical margin at gastrectomy. Anticancer Res., 17(1B), 689-694.

Harrison, L.E., Karpeh, M.S., Brennan, M.F. (1998). Extended lymphadenectomy is associated with a survival benefit for node-negative gastric cancer. J. Gastrointest. Surg., 2(2), 126-131.

Kunisaki, C., Akiyama, H., Nomura, M. (2006). Surgical outcomes in patients with T4 gastric carcinoma. J. Amer. Coll. Surg., 202(2), 223-230.

Maeta, M., Yamashiro, H., Saito, H. (1999). A prospective pilot study of extended (D3) and superextended para-aortic lymphadenectomy (D4) in patients with T3 or T4 gastric cancer managed by total gastrectomy. Surgery, 125(3), 325-331.

Nanthakumaran, S., Fernandes, E., Thompson, A. M., Rapson, T., Gilbert, F. J., Park, K. G. (2005). Morbidity and mortality rates following gastric cancer surgery and contiguous organ removal, a population based study. Eur. J. Surg. Oncol., 31(10), 1141-1144.

Roviello, F., Marrelli, D., Morgagni, P. (2002). Survival benefit of extended D2 lymphadenectomy in gastric cancer with involvement of second level lymph nodes: A longitudinal multicenter study. Ann. Surg. Oncol., 9(9), 894-900.

Sano, T., Mudan, S.S. (1999). No advantage of reoperation for positive resection margins in node positive gastric cancer patients? Jpn. J. Clin. Oncol., 29(6), 283-284.

Sasako, M., Sano, T., Yamamoto, S. (2008). D2 lymphadenectomy alone or with para-aortic nodal dissection for gastric cancer. New Engl. J. Med., 359(5), 453-462.

Siewert, J.R., Bottcher, K., Roder, J.D., Busch, R., Hermanek, P., Meyer, H.J. (1993). Prognostic relevance of systematic lymph node dissection in gastric carcinoma. German Gastric Carcinoma Study Group. Brit. J. Surg., 80(8), 1015-1018.

Songun, I., Bonenkamp, J.J., Hermans, J., van Krieken, J.H., van de Velde, C.J. (1996). Prognostic value of resection-line involvement in patients undergoing curative resections for gastric cancer. Eur. J. Cancer, 32A(3), 433-437.

\section{KUN̦G̣A VĒŽA EPIDEMIOLOG̣IJA UN K̦IRURG̣ISKĀ ĀRSTĒŠANA LATVIJĀ}

Lai gan mirstība no kuṇǵa vēža Rietumeiropā un Amerikas Savienotajās valstīs samazinās, Austrumeiropā tā joprojām ir augsta. Šī pētījuma nolūks bija novērtēt Latvijas Onkoloğijas centrā veiktās kuṇǵa vēža k̦irurǵiskās ārstēšanas īstermiṇa un ilgtermiṇa rezultātus. Statistiskajai analīzei tika izmantota retrospektīvi apkopota informācija par 461 pacientu, kam, laika posmā no 2001. gada janvāra līdz 2005. gada decembrim, Latvijas Onkolog̣ijas centrā ārstnieciskos nolūkos tika veikta gastrektomija. Katru gadu tika veiktas vidēji 92,2 (81-102) R0-R1 gastrektomijas. Pēcoperācijas komplikācijas tika novērotas 75 pacientiem (16,3\%), bet stacionārā mirstība bija 3,3\%. Piecu gadu izdzīvošana bija 50,8\%. 444 gadījumos $(96,3 \%)$ bija R0 rezekcijas histopatoloǵijas apstiprinājums un piecu gadu izdzīvošana $52,5 \%(P<$ 0,001). N̦emot vērā pT kategorijas, piecu gadu izdzīvošana pT1 pacientiem bija 88,6\%, pT2 - 65\%, pT3 - 42,3\% (35,7 mēneši) un pT4 $27 \%$ (14,2 mēneši). N̦emot vērā pN kategorijas, piecu gadu izdzīvošana pN0 pacientiem bija 67\%, pN1 - 30\% (22,1 mēnesis) un pN2-3 $29 \%$ (14,2 mēneši) $(P<0,001)$. Klīniski patoloğiskais pacientu raksturojums, kuriem ārstnieciskos nolūkos veikta rezekcija, ir salīdzināms ar Rietumu pieredzi. Arī îstermiṇa un ilgtermiṇa rezultāti ir līdzīgi, izṇemot pN+ pacientus, kuriem netika novērota atškiirība starp pN1 un pN2 gadījumiem. 